\title{
The unexpected profile of agricultural innovators: evidence from an empirical study
}

\author{
Rosa M. Yagüe-Perales*, Pau Pérez-Ledo*, Isidre March-Chorda*
}

\author{
DOI: $10.30682 / \mathrm{nm} 2002 \mathrm{f}$ \\ JEL codes: O13, O32, Q12
}

\begin{abstract}
Innovation capacity is essential for farmers to remain competitive and overcome the challenges facing Mediterranean agricultural systems. Based on an extensive empirical study, this paper elucidates the common attributes of innovative farmers in the Region of Valencia (Spain). The model presented in this study investigates whether an innovative attitude can be explained by market-entrepreneurial orientation, learning orientation, individual profile traits and farm size. The findings provide insights into how age and experience affect innovation in agricultural smallholdings. The study shows that the most innovative farmers run large farms and have a strong market-entrepreneurial orientation. Farm size and learning orientation are key requirements to enhance the innovative attitude of farmers.
\end{abstract}

Keywords: Learning, Innovation, Farmers, Profile, Valencia, Orientation.

\section{Introduction}

Innovation is related to the versatility and capacity to adapt to changing market demands. Accordingly, innovation determines whether certain economic activities will prosper or disappear. The agricultural economy is subject to rapid change. Here, innovation can act as a key factor, driving regional development. Accordingly, innovation is a key factor in successfully overcoming the challenges facing Mediterranean agriculture. Traditionally, the literature describes agriculture as a sector with low innovation intensity (Connor and Schiek, 1997) and with limited capacity to generate innovations on its own. Some authors consider agriculture a net recipient of indirect innovations, import- ing knowledge and solutions from other sectors (Alba et al., 2010).

This empirical study examines the Spanish region of Valencia (Comunitat Valenciana), which is located on the Mediterranean coast. The human capital in Mediterranean agricultural systems has several idiosyncrasies that are worth noting. Most farms are run by only one farmer who is not necessarily the owner. These farmers are generally old, and a large proportion of them are aged over 60 years.

The literature on innovativeness at the individual level suggests that farmers with more business experience should display a more innovation-oriented attitude. In contrast, the effect of age on innovative capacity has been reported as negative (Parsons, 2015), whilst

\footnotetext{
* Universitat de Valencia, Spain.

Corresponding author: isidre.march@uv.es
} 
other studies have provided inconclusive findings (Ng and Feldman, 2013). Our study addresses this gap by providing new findings and insights into how age and experience affect innovation in agricultural smallholdings. More specifically, the main objective of this paper is to characterise the innovative profile of farmers in the Spanish region of Valencia, identifying demographic traits and variables that drive innovative behaviour. Our findings contribute to understanding the factors that characterise innovative agricultural holders. Our findings also identify the areas that should be supported by public or private actors to make agricultural holders more competitive and better integrated in the regional economy.

Studies of farmers' innovative behaviour are nothing new (Mutsvangwa-Sammie et al., 2017; García Álvarez-Coque et al., 2018). However, some questions remain unanswered, including how market and entrepreneurial orientation and learning orientation influence smallholders' innovative attitudes. This study contributes to the debate on innovation in the agriculture sector by showing who innovative farmers are and, more specifically, identifying their common attributes. Our empirical findings will enrich the literature by revealing the conditions that enhance or deter innovative attitudes in farmers in the Region of Valencia, which is representative of the Mediterranean agricultural system

In summary, the specific objectives of the study are as follows: to broaden existing knowledge of the profile of agricultural holders in the Mediterranean region of Valencia in relation to their innovative attitudes; to identify the factors or dimensions that underpin innovative behaviour in farmers; and to describe the sociodemographic profile of a typical farmer in Valencia in terms of innovative attitude traits.

This study combines analysis of structural factors of agricultural holdings with the examination of behavioural aspects that may lead to open innovation behaviour. Based on survey data, the empirical approach combines factor analysis of constructs reflecting famers' behavioural characteristics with fuzzy-set qualitative comparative analysis (fsQCA) of a sample of agricultural holders.
The paper is structured as follows. The literature on individual innovativeness is first reviewed in search of the features linked to a broader innovative attitude. Special attention is paid to market orientation (MO), learning orientation (LO) and the influence of age. Next, the model and sample are described. The results of a factor analysis are then presented. Following this, the results of the qualitative comparative analysis and the main findings of the study are provided. The final section discusses the findings and offers some policy, managerial and scholarly implications.

\section{Individual innovation factors: a review of the literature}

The study of innovation in relation to agriculture and the rural world is nothing new. However, few studies of the Mediterranean have focused on the protagonists of this innovation, namely the farmers themselves. Most studies of agricultural innovation have focused on agri-food businesses instead. For example, García Álvarez-Coque et al. (2013), who also examined the Spanish region of Valencia, showed that innovation activities of agri-food firms depend on the firm's structure as well as the characteristics of the region where the firm is located. They reported that spatial considerations are especially relevant in determining an agribusiness's propensity to innovate. This paper adopts a different focus. Instead, it addresses the innovative behaviour of individual farmers, namely smallholders.

Despite various attempts (Alonge and Martin, 1995; Ruttan, 2000) to develop a theoretical framework and method to evaluate the process of innovation diffusion in the agri-food sector, measurement of the role and impact of innovation in this sector has proven difficult (Prokopy et al., 2008). Studies have attempted to explain the diffusion of innovations by focusing on farm structures (Dedieu et al., 2009), the generation and dissemination of knowledge and information (Röling, 1990), and the network of actors and institutions involved in the agricultural innovation system (Klerkx et al., 2012).

Measuring an individual's innovative attitude is also a challenge. Individual innovativeness is 
a persistent trait or disposition that determines how an individual perceives and reacts to innovation. As noted by Ali (2019), few studies have dealt with innovativeness in the context of an individual's willingness to develop new ideas. Indeed, it is more common for studies to provide evidence of the impact of personality traits on innovativeness (Buchanan, 1998; Hsieh et al., 2011; Rossberger, 2014; Steel et al., 2011).

As Aldahdouh et al. (2019) recently reported, individual innovation has been operationalised using two principal methods. The first relies on the approach described by Rogers (2003), who defined innovativeness as the degree to which a unit of decision, typically an individual, adopts new ideas earlier than other members of a system. A second and more abstract measurement method conceptualises innovativeness as a persistent individual characteristic. This view was introduced by Hurt et al. (1977a), who proposed a 20-item scale to measure innovativeness as a global personality trait characterised by a willingness to change or a willingness to try new things. The original scale contained items measuring this concept as well as items identifying a creative and original person.

The Five-Factor Model (the 'Big Five'), which was proposed by McCrae and Costa (1999), is a widely used and well-recognised model to link personality traits to innovativeness. Similarly, Dyer et al. (2009) argued that the capacity to innovate stems from a number of behavioural abilities (questioning, observing, networking and experimenting) and cognitive skills associated with challenging the status quo and risk-taking. Sidhu et al. (2016) also advocated psychological analysis of a company's employees by focusing on an individual's innovation mindset, which is based on six items: trust, resilience, diversity, confidence, collaboration and resource awareness. In conclusion, a broad stream of literature places psychological factors ahead of organisational factors as the primary contributors to individual innovativeness.

When analysing individual innovativeness, most studies have focused on employees to determine the extent to which certain personality traits affect employees' motivation and tendency to behave in an innovative manner. However, scant research has addressed the innovativeness of individual business owners, which more accurately describes the status of most farmers in Mediterranean regions. In this setting, innovative capacity directly depends on the innovation-led attitudes and behaviours of the individuals who run the farms. This context supports our decision to adopt the personality trait approach to innovativeness.

Few efforts have been made to understand individual agricultural innovators, especially with respect to smallholders. Mutsvangwa-Sammie et al. (2017) investigated the profile of local innovators in a smallholder farming area in southwest Zimbabwe. The data were collected from key informant interviews and a questionnaire completed by 239 households. Qualities or attributes of innovators (i.e. what constitutes the profile of innovators) were identified by key informants. These attributes include resource endowment, social networks, education and enthusiasm.

Furtan and Sauer (2008) identified several factors that lead to more innovative behaviour in the agri-food businesses. These factors include type of ownership, the value chain, the capacity to develop new products, employee motivation, competitive position and strategic factors. Magne et al. (2010) developed a model to enhance the information flowing towards farmers to improve their capabilities and decision-making processes.

Most farmers tend to have a low propensity to interact and establish collaborative agreements with research centres (Maghni and Oukaci, 2018). In connection with this relationship between farmers and innovation intermediaries, García Álvarez-Coque et al. (2018) explored smallholdings' perceived benefits of using research services. An innovative attitude was proposed as an exogenous variable in a structural equation model.

This literature review highlights the factors that are especially relevant for innovation in agriculture. By focusing on the characteristics of agricultural innovators, we address the innovation process from the perspective of innovators to understand the process as a whole. Although authors such as Fagerberg (2003) have argued that innovation is inherently char- 
Table 1 - References on innovation and the factors that determine innovation.

\begin{tabular}{|l|l|}
\hline \multicolumn{1}{|c|}{ Innovation Factors } & \multicolumn{1}{c|}{ References } \\
\hline Market and entrepreneurial orientation & $\begin{array}{l}\text { Atuahene-Gima (1996) } \\
\text { Aldas-Manzano, Küster, and Vila (2005) } \\
\text { Zhou } \text { et al. } \text { (2005) } \\
\text { Dimitratos } \text { et al. (2004) } \\
\text { Sidhu } \text { et al. (2016) }\end{array}$ \\
\hline Innovativeness & $\begin{array}{l}\text { Cheng and Shiu (2008) } \\
\text { Calantone, Cavusgil, and Zhao (2002) } \\
\text { Hollenstein (1996) } \\
\text { Hurt, Joseph, and Cook (1977) } \\
\text { Hurt and Teigen (1977) }\end{array}$ \\
\hline Competitive pressure & Sophonthummapharn (2009) \\
\hline Uncertainty & $\begin{array}{l}\text { Dimitratos } \text { et al. (2004) } \\
\text { Segarra-Blasco and Arauzo-Carod (2008) }\end{array}$ \\
\hline \multirow{2}{*}{ Cooperation } & $\begin{array}{l}\text { Sophonthummapharn (2009) } \\
\text { Segarra-Blasco and Arauzo-Carod (2008) } \\
\text { Okamuro (2007) }\end{array}$ \\
\hline Learning orientation & $\begin{array}{l}\text { Hurley and Hult (1998) } \\
\text { Johnson } \text { et al. (1997) } \\
\text { Calantone, Cavusgil, and Zhao (2002) }\end{array}$ \\
\hline Outcomes and future performance & Fortuin and Omta (2009) \\
\hline Outcomes and current performance & $\begin{array}{l}\text { Jaw, Lo, and Lin (2010) } \\
\text { Fortuin and Omta (2009) } \\
\text { García Álvarez-Coque et al. (2018) }\end{array}$ \\
\hline
\end{tabular}

Source: Compiled by the authors.

acterised by aspects other than individual capabilities (e.g. uncertainty), we focus on the attributes of farmers themselves. Therefore, we exclude uncertainty and competitive pressures from this analysis, considering these factors contextual elements that should be further explored in future studies. Furthermore, we do not seek to study the performance of the innovation process but rather explain what leads to an innovative attitude.

The summary of the literature review (Table 1) reflects the importance of linking innovation to the market. Farming entrepreneurs are expected to excel in two areas that the literature suggests are essential to innovate: market orientation (MO) and learning orientation (LO). Baker and Sinkula (1999) are considered the first scholars to have linked MO and LO to firm innovativeness. They conclude that both LO and MO are key to successful product innovation and performance.
Most scholars accept that MO contributes to employee satisfaction, organisational commitment and confidence in a business's future performance (Zhou et al., 2005a). MO is becoming a more prominent research theme in a context of growing competitiveness, volatility and further pressures from rapid changes in customer needs and desires (Aldas-Manzano et al., 2005). MO positively affects a business's resources and exerts a powerful influence on innovation capacity and business behaviour (Jaw et al., 2010; Atuahene-Gima, 1996). The main value of MO lies in supporting and enhancing the innovative product or service features that are most highly valued by prospective customers. Accordingly, MO enables entrepreneurs to design innovations that are better aligned with customer expectations, thereby reducing the risk of commercial failure. MO is also linked to entrepreneurial capacity. The literature links entrepreneurial orientation to innovation predominantly at the business level. 
A strong company entrepreneurial orientation is expected to lead to a strong company innovation capacity (Hult et al., 2003; Zhou et al., 2005 b) or at least behave as promoter enhancer of innovation (Rauch et al., 2009).

LO positively influences a business's innovativeness (Keskin, 2006; Hurley and Hult, 1998). Hurley and Hult (1998) linked high levels of innovation to cultures of learning, development and participation in decision making. LO embodies the degree to which businesses are committed to systematically challenging the fundamental beliefs and practices that define the innovation process itself. In addition, businesses with a strong LO are more willing to question the long-held assumption that market-oriented behaviours lead to successful innovation in any situation (Baker and Sinkula, 1999). Calantone et al. (2002) defined four components of LO: commitment towards learning, shared vision, open-mindedness and shared intraorganizational knowledge. Rezai et al. (2011) highlighted the importance of informal learning in promoting entrepreneurship amongst farmers. The focus on learning should be intensified, and farmers should be encouraged to focus not only on modern technologies but also on fundamental changes in their attitudes to view agriculture as a business.

Our model of innovativeness considers additional features of the individuals who run farms in relation to their age and organisational experience. The individuals who run individual farms in the Region of Valencia, and indeed in most Mediterranean regions, are generally older. Therefore, age is worthy of analysis. The findings in the literature on the role of age in innovative attitudes are scarce and somewhat contradictory. $\mathrm{Ng}$ and Feldman (2013) found no relationship between age and innovation. This finding contradicts the widespread negative stereotype that older and longer-tenured workers are less innovative and more reluctant to change. Consequently, excluding older workers from innovation-related tasks might be counterproductive. Parsons (2015) explored how age drives individuals to innovate. The age and experience are expected to increase the probability of the success of innovation-led projects. However, older employees have a tendency to adhere to prevailing procedures. Successful senior employees have already enjoyed success with existing methods, processes and practices. Therefore, most would prefer not to risk their careers through involvement in innovative projects, which usually entail uncertainty.

The process of farm innovation is not based solely on farmers' individual competencies and actions. In the context of agricultural and rural innovation, social capital is widely considered to provide access to resources that foster farm innovation. Such resources include not only knowledge and funding but also moral support. According to Cofré-Bravo et al. (2019), farm innovation is also influenced by farmers' social networks, which provide relevant knowledge and other resources. This argument was proposed by Micheels and Nolan (2016), who affirmed that social capital is more important than farm size in determining the number of technologies and practices that are adopted. Social capital is included in our model as part of farmers' overall experience.

In light of this review, we propose innovation attitude as the main outcome we wish to explain and behavioural and socioeconomic characteristics of individual farmers as potential causal conditions. We measure behavioural factors and combine them as components of configurations that lead to the presence or absence of a prominent innovation attitude in farmers.

\section{General model and sample}

\subsection{Model}

As described below, fsQCA was used to express the outcome of interest in terms combinations of causal conditions. Our goal was to explain what drives farmers to innovate. Innovative attitude was therefore taken as the main outcome. The variables selected from the questionnaire and used as causal conditions in our model were age, farm size, years of professional experience, market-entrepreneurial orientation (MO) and LO. The model is illustrated in Figure 1. 
Figure 1 - Causal conditions affecting innovative attitude.

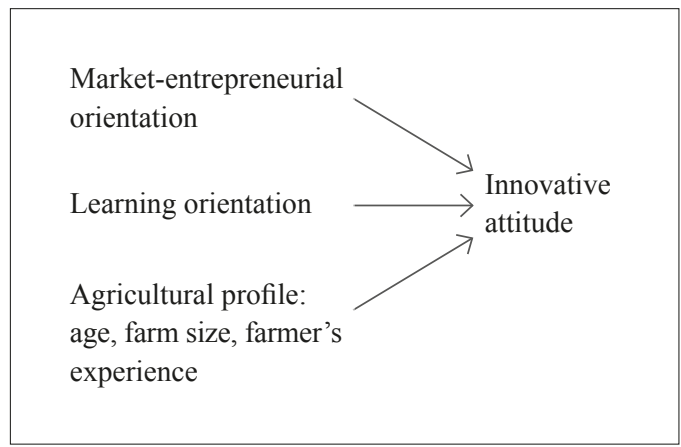

The purpose of this model was to determine the extent to which the innovative attitude of farmers in the Region of Valencia (Spain) can be explained by market and entrepreneurial orientation, learning orientation, and individual background (i.e. age, farm size and professional experience). Data for the individual background variables were gathered using the survey. Data on innovative attitude, market and entrepreneurial orientation, and LO were derived using factor analysis of items from the survey that reflect holders' behaviour.

\subsection{Sample}

The geographical context of the present study is the Region of Valencia (Spain). This region has two very different agricultural systems: coastal irrigated agriculture and dry inland agriculture. The latter is more comparable to continental agriculture. These systems are separated by a transition zone (Picazo Tadeo and Hernández Sancho, 1993). Valencian agriculture, especially irrigated agriculture, relies heavily on skilled human capital, the result of a long socio-agricultural tradition that is deeply rooted in Valencian cultural values (García Ferrando et al., 1994).

Mediterranean agricultural systems face major challenges. These challenges include a decrease in the profitability of agricultural smallholdings, which has been aggravated by the fragmented ownership structure that has hindered modernisation. Farm structures are characterised by the predominance of part-time agriculture, leading to the progressive abandonment of crops and the ageing of the active population in this sector. These factors have eroded human capital, hampering the sustainability of agriculture in many Southern European regions (Compés López et al., 2009). As Compés López et al. (2019) reported, these difficulties in the traditional Valencian agricultural system have worsened in recent years.

The unit of study was the agricultural holding. Selected holdings were involved in both plant and animal production. The holdings had an area equal to or greater than $831 \mathrm{~m}^{2}$, a common measure of land area in Valencia. The subject of the survey was the person responsible for taking decisions concerning the farm. This person was not necessarily the landowner. Primary data were collected through key informant interviews. These informants were identified with the help of professional organisations such as the IVIFA foundation (Valencia Cooperative Federation or Fundación Instituto Valenciano de Investigación y Formación Agroambiental) and la Unió, which is a farmers' organisation. The survey was completed in spring 2012, but more recent data on the individual behaviour of farmers in the region were unavailable. Farm Structure Surveys published by Eurostat, most recently in 2016, do not provide data on the behavioural variables required to pursue our research objectives. For example, the Farm Structure Surveys do not provide data on innovation, MO or LO. The final questionnaire was completed by 253 individuals throughout the Region of Valencia. More than $70 \%$ of respondents were located in the Province of Valencia, with the remaining respondents located in the Province of Castellón and the Province of Alicante. The questionnaire was used to gather data on key points raised during the key informant interviews in a prior focus group. Data were collected on individual socioeconomic characteristics and scales, which were divided into three blocks: LO, market-entrepreneurial orientation and innovative attitude. A detailed list of the scales can be found in the paper by García Álvarez-Coque et al. (2014).

The survey enabled the study of items that define agricultural innovators, which was the outcome in the factor analysis and fsQCA. The 
Table 1 - Respondent characteristics.

\begin{tabular}{|l|c|c|c|}
\hline \multicolumn{1}{|c|}{ Variable } & Frequency & Mean & Standard deviation \\
\hline Age (years) & & 49.43 & 11.658 \\
\hline Under 40 & 53 & & \\
\hline Between 40 and 65 & 179 & & \\
\hline Over 65 & 15 & & \\
\hline Farm size (Ha) & & 18.97 & \\
\hline Under 5 & 92 & & \\
\hline Between 5 and 20 & 106 & & \\
\hline Over 20 & 49 & & \\
\hline
\end{tabular}

Source: Survey data.

structured questionnaire contained objective variables that define the farmer's profile. These variables include age, gender and farm size as well as factors to measure organisational aspects of the farm. The items that correspond to each variable were measured using a 7-point Likert scale. The questionnaire was also used to gather data on farm location, farm size, participation in agricultural associations, years of experience running the farm, type of crop, form of employment (part-time or full-time), number of employees (if any), ownership structure and production methods. Finally, the three main constructs of MO, LO and innovative attitude were operationalised using a large number of items.

The average age of the farmers in the sample was 49 years. The age groups were under 40 years old, between 40 and 65 years and over 65 years. Farm size was defined by three brackets: $<5 \mathrm{Ha}, 5-20 \mathrm{Ha}$ or $>20 \mathrm{Ha}$. Table 1 shows the respondent characteristics in terms of age and farm size.

\section{Factor analysis}

To summarise the information and minimise any losses, factor analysis was conducted for the construct of innovative attitude. This factor analysis was based on the 10 questionnaire items used to reflect farmers' innovative behaviour and form this construct. Initial exploratory factor analysis (R-type) with varimax rotated principal component analysis was used to generate general groups of farmers according to their innovative attitude. The construct defines the presence or absence of the outcome.
The assumptions for factor analysis were not violated. The value of the Kaiser-Meyer-Olkin $(\mathrm{KMO})$ test was 0.890 , which implied that the data were well suited to the factor model. According to Bartlett's test, the level of critical significance was 0.000 , which indicated that the correlation coefficients between each pair of variables were significantly different from 0 . Therefore, the variables were correlated.

The corresponding correlation matrix showed that $60 \%$ of residues had absolute values greater than 0.05 . Thus, the fit of the data to the estimated model was $60 \%$, which was considered acceptable. The 10 variables that referred to the innovative attitude construct were subjected to principal component factor analysis. The method selected two principal components that explained $54.35 \%$ of the variance. After rotation of the common factors using the varimax method, Factor 1, which explained $42 \%$ of the variance, was taken as representative of the construct. Factor 1 had a high positive correlation (greater than 0.7 ) with six of the 10 initial variables. These variables included 'Innovating is worthwhile', 'Innovating improves performance' and 'I value innovators'. This factor was considered representative of innovative attitude and was named 'FInnoatt'.

The constructs of market and entrepreneurial orientation and LO had six and seven items each. To operationalise MO as a first-order factor, we used the MARKOR scale from the literature (Kohli et al., 1993). LO was operationalised using a scale based on Baker and Sinkula's (1999) proposal as well as some additional features. To classify all farmers in the sample, a 
unique and continuous value was needed. The most suitable solution consisted of a factor analysis that categorised the initial items into just one or two factors.

A factor analysis of LO was conducted based on the six questionnaire variables used to form this construct. We first validated the factor model. According to Bartlett's test, the critical significance was 0.000 . Therefore, it was assumed that the variables were correlated. The value of the KMO test was 0.791 , which implied that the data fit the factor model. Finally, the correlation matrix showed that $86 \%$ of residues had absolute values greater than 0.05 . Therefore, the fit of the data to the estimated model was $86 \%$. The first factor summarising LO accounted for $47.29 \%$ of total variance. This percentage was considerably higher than the percentage corresponding to the second factor, which had an explanatory capacity of $15 \%$. Thus, Factor 1, named 'Flearn', was considered representative of LO. The Flearn factor had a positive and similar correlation with all variables in the construct. Therefore, this factor was deemed fully representative of LO.

The factor analysis of market and entrepreneurial orientation was applied to the six questionnaire variables used to form this construct. To validate the factor model, we used Bartlett's test. The critical significance was 0.000 . Therefore, it was assumed that the variables were correlated. The value of the KMO test was 0.768 , which implied a good fit of the data to the factor model. Finally, the correlation matrix showed that $86 \%$ of residues had absolute values greater than 0.05 . Therefore, the fit of the data to the estimated was $86 \%$. The six variables that formed market and entrepreneurial orientation were subjected to principal component analysis. The two principal components selected explained $58,65 \%$ of the variance. The factor of market and entrepreneurial orientation accounted for $41.47 \%$ of the total variance, which far exceeded the $17.17 \%$ explained by the second factor. Thus, Factor 1 (Fmentror) was accepted as representative of market and entrepreneurial orientation. Fmentror had a high positive correlation with four of the six original variables. The two most relevant original variables in this factor were customer satisfaction and quality orientation.

\section{Qualitative comparative analysis}

\subsection{FsQCA method}

FsQCA is a set-theoretic analysis technique that enables identification of the causal conditions that lead to an outcome. This technique is useful for analysing causal processes under conditions of high causal complexity and can be used to find the causes that combine to bring about outcomes (Fiss, 2007).

The data from the interviews provided a rich set of measures of the variables in the general model. The non-parametric fsQCA technique was used. Unlike standard regression methods, fsQCA has the advantage of not requiring the assumption that data are drawn from a given probability distribution. In fsQ$\mathrm{CA}$, constructs are measured using calibrated sets. Calibration reduces sample dependence. Set membership is defined based on substantive knowledge rather than the sample mean, thereby reducing the importance of sample representativeness (Fiss, 2011).

As a set-theoretic technique, fsQCA can be used to examine causal patterns by focusing on set-subset relationships. Therefore, drawing on research by Fiss (2011), fsQCA was used to discover the behaviour and attributes that lead to an innovative attitude in famers. FsQCA can be used to identify the combinations of attributes associated with the outcome of interest (i.e. high innovativeness of farmers), using Boolean algebra and algorithms to logically reduce numerous, complex causal conditions into a small number of configurations that lead to the outcome.

To empirically identify these causal processes, fsQCA has three steps. After the independent and dependent measures have been transformed into sets, the first step is to use these set measures to construct a data matrix known as the truth table. The truth table has $2^{\mathrm{k}}$ rows, where $\mathrm{k}$ is the number of causal conditions used in the analysis.

In the second step, the number of rows is reduced based on two criteria: the minimum number of cases required for a solution and the minimum consistency of a solution. Consistency in fuzzy sets is the proportion of cases that are consistent with the outcome. Acceptable consistency 
values for solutions must be above the minimum recommended threshold of 0.75 (Ragin, 2006; 2008). In the third step, an algorithm based on Boolean algebra is used to logically reduce the truth table rows into simplified combinations. Most applications of fsQCA use the truth table algorithm described by Ragin (2008).

Because the outcome measure is continuous, we performed continuous fuzzy-set calibration. Three anchors must be determined to compute the set membership values: two extreme points defining full membership and full non-membership and a cross-over point at which the agricultural holder is neither in nor out of the set (Ragin, 2000, pp. 158-159). These anchors are assigned set membership values of 1,0 and 0.5 , respectively. A value of 0 indicates that the condition is fully outside the set, a value of 1 indicates full membership to the set and a value of 0.5 usually denotes the point of maximum ambiguity. In this study, we set the anchor for full membership of agricultural holders' characteristics at 20\% higher than the overall mean. For full non-membership, a cut-off of 50\% lower than the overall mean was used. The point of maximum ambiguity was set as the sample mean. Continuous set membership values were then defined for all cases by applying the log odds method described by Ragin (2008). In the calibration of our five causal conditions, we assigned the anchor values of 0.95 and 0.05 .

The fsQCA method is used to identify relationships of sufficiency and necessity (Ragin, 2006). In fuzzy-set terms, a relationship of necessity implies that outcome $\mathrm{Y}$ is a subset of condition X. A condition is sufficient for an outcome to occur if it can, by itself, cause the outcome. In fuzzy-set terms, a sufficient condition would be a subset of the outcome. Thus, if set $\mathrm{X}$ is sufficient for outcome $\mathrm{Y}$, then set $\mathrm{X}$ 's fuzzy membership value is equal to or less than the fuzzy membership value of set Y (Ragin, 2008). A causal condition can be considered sufficient for the outcome if, for each case, the fuzzy membership value of the causal condition $\mathrm{X}$ does not exceed the fuzzy membership value of the outcome Y (Ragin, 2000, p. 235). Conventionally, a condition is called necessary or almost always necessary if the consistency score exceeds the threshold of 0.9 .
The five causal conditions included in the model were age, farm size, professional experience, Fmentror (factor of market and entrepreneurial orientation) and Flearn (factor of LO). We used the following cut-offs for the constructs: negative $\rightarrow 0.05$, greater than $1 \rightarrow 0.95$ and ambiguous $[0,1] \rightarrow 0.50$. The innovative attitude factor ranged from -2.89 to 1.28 , so the negative values were considered to denote full non-membership and were assigned a fuzzy membership score of 0.05 . The value 0.95 was assigned to cases with full membership (i.e. with values greater than 1). Finally, the point of maximum ambiguity (i.e. 0.5 ) was assigned to cases with values between 0 and 1 .

The empirical analysis can be interpreted as explaining the presence of innovative attitude based on the following conditions: age, experience, size of the farm, the LO factor and the market-entrepreneurial orientation factor. The fsQCA model may be stated as follows:

$$
\begin{aligned}
& \text { FInnoatt }=\mathrm{f}(\text { age }+ \text { experience }+ \text { size }+ \text { Flearn } \\
+ & \text { Fmentror })
\end{aligned}
$$

\subsection{QCA findings}

Consistent with the theoretical framework, the necessary and sufficient conditions were examined for the presence of the outcome (i.e. innovative attitude or FInnoatt) in the sample of farmers from Valencia. A condition is considered necessary if the consistency value exceeds the threshold of 0.90 (Ragin, 2008; Schneider and Wagemann, 2010).

The model's solutions describe the presence of the outcome (FInnoatt) in terms of the presence or absence of relevant conditions in the fuzzy sets. Absence is expressed using the symbol ' $\sim$ '. The conditions that lead to the absence of an innovative attitude can also be identified. The presence of an innovative attitude in the fuzzy set is expressed as fs_fInnoatt, whereas the absence is expressed as $\sim$ fs_fInnoatt. Note that presence of the age condition (fs_age) means that farmers are young.

As Table 2 shows, no condition exceeded the threshold of 0.90 . Accordingly, no single condition explained the presence of an innova- 
Table 2 - Analysis of necessary conditions.

\begin{tabular}{|c|c|c|c|c|}
\hline \multirow{2}{*}{ Construct } & \multicolumn{2}{|c|}{ Innovative attitude (a) } & \multicolumn{2}{|c|}{ Non-innovative attitude(b) } \\
\hline & Consistency & Coverage & Consistency & Coverage \\
\hline fs age & 0.696 & 0.709 & 0.648 & 0.606 \\
\hline fs age & 0.613 & 0.655 & 0.689 & 0.675 \\
\hline fs_exper & 0.559 & 0.742 & 0.555 & 0.675 \\
\hline$\sim \overline{f s}$ exper & 0.755 & 0.649 & 0.788 & 0.621 \\
\hline fs fmentror & 0.769 & 0.749 & 0.638 & 0.570 \\
\hline fas fmentror & 0.558 & 0.627 & 0.719 & 0.740 \\
\hline fs_flearn & 0.801 & 0.781 & 0.602 & 0.538 \\
\hline$\sim \overline{\mathrm{fs}}$ _flearn & 0.526 & 0.590 & 0.754 & 0.776 \\
\hline fs surf & 0.620 & 0.710 & 0.581 & 0.609 \\
\hline$\sim \overline{f s}$ surf & 0.659 & 0.632 & 0.724 & 0.636 \\
\hline
\end{tabular}

(a) In the analysis of necessary conditions for an innovative attitude, presence of the causal conditions was considered.

(b) In the analysis of necessary conditions for a non-innovative attitude, absence of the causal conditions was considered.

tive or non-innovative attitude in the observed cases. However, $f_{s}$ flearn (consistency $=0.80$ ) appeared to be an important condition for an innovative attitude. The absence of experience ( $f f_{-} \_$exper $)$appeared to be an important condition for a non-innovative attitude. These findings are relevant in that they suggest that no condition in Table 1 seems to limit or prevent the presence of innovative farmers. Therefore, farmers in the Region of Valencia do not need to meet any specific conditions to have an innovative attitude. The results indicate that LO is the closest thing to a necessary condition for farmers to have an innovative attitude.

The next step was to perform an analysis of sufficient conditions. Table 3 shows the intermediate solution for the outcome of innovative attitude. The three configurations are those whose consistency surpassed the minimum threshold for consistency established by Ragin (2000). The model can be expressed as follows: fs_finnovaatt $=\mathrm{f}\left(\mathrm{fs} \_\right.$age, fs_exper, fs_fmentror, fs_flearn, fs_size)

The Quine-McCluskey algorithm was used for the analysis. The intermediate solution is the most commonly used solution in fsQCA (García Álvarez-Coque, 2017; Nieto Alemán et al., 2018). We therefore considered this solution.

Tables $3 \mathrm{a}$ and $3 \mathrm{~b}$ present the causal configurations that lead to high rates of farmers with and without an innovative attitude in the Re- gion of Valencia. The results are presented using García Álvarez-Coque et al.'s (2017) notation. The solutions for an innovative attitude and a non-innovative attitude have consistency values of 0.812 and 0.786 , respectively. Although these configurations may be sufficient to explain the presence or absence of innovative attitude in the individuals in the sample, they do not necessarily cover all possible solutions. These outcomes may also be due to the presence or absence of other conditions. Nevertheless, the emergence of different configurations suggests that more than one pattern can lead to innovativeness amongst farmers in the Region of Valencia. In addition, the pathways do not refer to single conditions but rather combinations of factors that lead to the presence or absence of an innovative attitude in farmers.

Table 3a shows three solutions that lead to an innovative attitude in farmers in Valencia. Solution I indicates that farmers tend to have an innovative attitude when they are young, are experienced and have a strong market-entrepreneurial orientation. Solution II indicates that farmers also have an innovative attitude when they are young, are experienced and run large farms. Finally, Solution III indicates that famers have an innovative attitude when they are old, are experienced, have a strong LO and run small farms.

For the absence of an innovative attitude, Solutions V and VII in Table 3 have the highest 
Table 3 - Analysis of sufficiency: farmers with and without an innovative attitude (intermediate solution).

\begin{tabular}{|c|c|c|c|}
\hline & Raw coverage & Unique coverage & Consistency \\
\hline $\begin{array}{l}\text { 3a. Outcome: innovative attitude } \\
\text { I fs_age*fs_exper*fs_fmentror } \\
\text { II fs_age*fs_fmentror*fs_size } \\
\text { III } \sim \text { fs_age*fs_exper*fs_flearn* fs_size } \\
\text { solution coverage: } 0.781878 \\
\text { solution consistency: } 0.811831 \\
\text { frequency cut-off: } 1 \\
\text { consistency cut-off: } 0.873948 \\
\text { 3b. Outcome: non-innovative attitude } \\
\text { IV } \sim \text { fs_flearn* ffs_size } \\
\text { V } \sim \text { fs_fmentror* ff_flearn } \\
\text { VI } \sim \text { fs_exper* ffs_flearn } \\
\text { VII fs_age* } \sim \text { fs_flearn } \\
\text { solution coverage: } 0.75126 \\
\text { solution consistency: } 0.786487 \\
\text { frequency cut-off: } 1 \\
\text { consistency cut-off: } 0.842967\end{array}$ & $\begin{array}{l}0.413668 \\
0.423214 \\
0.309872\end{array}$ & $\begin{array}{l}0.0179325 \\
0.0181803 \\
0.0197505 \\
0.0042145\end{array}$ & $\begin{array}{l}0.802667 \\
0.848342 \\
0.815993 \\
0.832346\end{array}$ \\
\hline
\end{tabular}

Note: ( ) absence of the condition; (*) logical operator 'and'.

consistency scores. Solution V indicates that an absence of an innovative attitude is caused by a weak market and entrepreneurial orientation and a weak LO. Solution VII suggests that young farmers with a weak LO have a non-innovative attitude.

\section{Discussion and conclusions}

The main aim of this paper is to define the profile of farmers with an innovative attitude. Our interest in this profile of farmers is justified by the fact that innovations are critical to improve the effectiveness and sustainability of agriculture. Few studies have systematically investigated the profile of innovators in agriculture. Studies that have explored the innovation capacity of farm holders and workers are even more scarce. Unlike most previous studies, which have typically focused on agri-food businesses rather than farmers (Hauser et al., 2010; Furtan and Sauer, 2008), our analysis sought to identify the indi- vidual-level factors behind an innovative attitude in the agriculture sector.

From a theoretical standpoint, this study offers new explanations for the innovative behaviour of individuals who run farms. The empirical study highlights several factors that drive an innovative attitude in farmers in the Region of Valencia.

Our findings provide valuable clues as to whether smallholders in the present context of farm fragmentation and ageing farmers are truly reluctant to adopt innovations. These findings are consistent with models that link personality traits to innovativeness (Hurt et al., 1977b; McCrae and Costa Jr., 1999). In addition, our results confirm that the capacity to innovate stems from behavioural abilities linked to informal learning, in line with Rezai et al. (2011).

A rigorous analysis using fsQCA shows the combinations of factors that explain or define the profile of agricultural innovators in the Region of Valencia. The fsQCA shows whether an innovative attitude is caused or explained by market-entrepreneurial orientation, LO, individ- 
ual profile traits and farm size. Although no condition is necessary for the presence or absence of an innovative attitude in farmers, combinations of several factors are sufficient for individuals to have an innovative attitude. LO is the only condition that comes close to being considered necessary for an innovative attitude.

By performing this study, we make several notable contributions. First, we identify the profile of the most innovative farmers and that of the least innovative farmers. Second, we reveal the conditions that lead farmers to behave in an innovative manner. Third, we show that the propensity to innovate in small agricultural businesses can be enhanced or hindered depending on the combination of personality traits, behaviours and external factors.

The findings have some important implications for policy and management. Our results show that younger farmers have higher levels of innovative attitude, provided they have sufficient experience running agricultural businesses. Being a young farmer in the context of the Valencian agricultural system means being less than 50 years old. In our sample, most farmers labelled as young and experienced were aged between 40 and 50 years.

Our findings also suggest that the most innovative farmers (i.e. young and experienced farmers) run large farms and have a strong MO. Consequently, the size of the farm is a key requirement for these farmers to decide whether to implement innovations of any kind. In addition, these farmers have a strong entrepreneurial attitude and are eager to satisfy the market's needs and expectations. Experience and training foster a dynamic and innovative attitude in farmers, as long as the farmers are relatively young and are willing to apply this knowledge to improve the productivity and quality of their farms. Usually, these farmers introduce several varied innovations, including new and more profitable crops, more productive irrigation systems, new commercialisation channels (e.g. online platforms and digital marketing), and involvement in collective storage and commercialisation structures. Agricultural policies that seek to enhance innovation in this sector should support the introduction of all these forms of innovation.
Age is a key driver of innovative attitude. Being older tends to deter innovative behaviour, which is more common in young individuals. To combat this weak innovative attitude in older farmers, policymakers should prioritise actions aimed at communicating and explaining the benefits of introducing changes and innovations that are more easily understood by these older farmers. Examples include collective storage and commercialisation structures and the introduction of new crops to replace traditional crops that are no longer profitable. Fortunately, our findings show that older experienced farmers have a high LO. Therefore, it is easier to convince them of the advantages of innovations that are beneficial to small farms, which are the types of farms they typically run. Our findings also contribute to the discussion on the relationship between age and innovative attitudes. By identifying the factors that may reduce older individuals' reluctance to innovate, our findings provide a more nuanced view than that which ascribes lower innovativeness to older individuals (Parsons, 2015).

The fsQCA provides two striking results. First, the configurations leading to presence of an innovative attitude show that for a strong LO to positively affect innovative attitude, farmers must be older. Once a sufficient LO is ensured, high levels of innovation are achieved by older, experienced individuals who run small farms. An initial explanation for this surprising result is that a minimum level of experience might be necessary to turn learning capacity into innovation. Agriculture is typically the main professional activity of the majority of older farmers. In contrast, young farmers tend to work parttime. An alternative explanation is that learning capacity, which is actually a proxy of experience and skills, is a requirement for older farmers to behave innovatively. In contrast, young farmers do not need high levels of LO to become innovators. For young farmers, a strong market-entrepreneurial orientation is more important than a strong LO to nurture their innovation capacity. Second, farm size is not always linked to a strong innovative attitude. Running a large farm only contributes to an innovative attitude if the farmer is young and has a strong market-entrepreneurial orientation. However, 
running a small farm leads to an innovative attitude when farmers are older, are experienced and have a strong LO.

Another implication of these findings is the link between the farmer's age and the two key constructs of LO and market-entrepreneurial orientation. LO seems to apply more to older farmers, whereas market-entrepreneurial orientation tends to be attributed to young farmers. Farmers who lack a sufficient level of LO are likely to fall into the non-innovative group if this lack of LO is combined with running a small farm or with having little experience running farms. Having low levels of LO and market-entrepreneurial orientation (i.e. the two main causal conditions) also leads to a non-innovative attitude in farmers. Consequently, our study attributes the absence of an innovation attitude to the lack of LO. Policymakers should be aware of the difficulties attached to overcoming a lack of willingness to learn.

These results indicate that the largely neglected group of older farmers running small agricultural holdings deserves recognition and further support from policymakers. The sharp decrease in the proportion of professional farmers has resulted in an average age of around 60 years, with more than one third aged over 65 years. Rather than ignoring this group, agriculture development programmes should be geared towards passing on and transferring older farmers' skills, experience and dynamism to young farmers.

This study has some limitations, primarily in relation to the sample size, which could be expanded in subsequent studies by including farmers from other regions in Spain. LO was identified in this study as an almost necessary condition, so it might be found to be a strictly necessary condition in a study using a larger sample. New variables linked to the farm itself should be added too. The selection procedure could be altered by consulting other agricultural organisations and associations. The cross-sectional nature of the study is not a serious drawback. A longitudinal study does not seem necessary given the extensive period needed for farmers to change their mindset and open up to more proactive and dynamic attitudes towards managing their farms.
From a practical perspective, our study illustrates the profile of innovators in agriculture. Our findings reveal the factors that must be present on their own or in conjunction with other factors to lead to innovative behaviour.

This profile can be used to help institutions and farming associations define their policies and promote innovative behaviour and values. The study can also improve our understanding of the needs, challenges and difficulties surrounding rural farming.

\section{References}

Alba Federico M., García Álvarez-Coque J.M., López-García Usach T., Mas-Verdú F., 2010. Conocimiento incorporado y vínculos sectoriales. El caso de una región con baja capacidad de absorción. Paper presented at the International meeting on regional science, "The Future of the Cohesion Policy", XXXVI Reunión de Estudios Regionales, AECR / $7^{\text {a }}$ Workshop APDR, Badajoz, 18-19 November, $21 \mathrm{pp}$.

Aldas-Manzano J., Küster I., Vila, N., 2005. Market orientation and innovation: an inter-relationship analysis. European Journal of Innovation Management, 8(4): 437-452, https://doi. org/10.1108/14601060510627812.

Aldahdouh T.Z., Korhonen V., Nokelainen P., 2019. What contributes to individual innovativeness? A multilevel perspective. International Journal of Innovation Studies, 3(2): 23-39.

Ali I., 2019. Personality traits, individual innovativeness and satisfaction with life. Journal of Innovation \& Knowledge, 4(1): 38-46, https://doi. org/10.1016/j.jik.2017.11.002.

Alonge A.J., Martin R.A., 1995. Assessment of the adoption of sustainable agriculture practices: Implications for agricultural education. Journal of $\mathrm{Ag}$ ricultural Education, 36(3): 34-42.

Atuahene-Gima K., 1996. Market orientation and innovation. Journal of Business Research, 35(2), 93-103, https://doi.org/10.1016/0148-2963(95) 00051-8.

Avolio G., Blasi E., Cicatiello C., Franco S., 2014. The drivers of innovation diffusion in agriculture: evidence from Italian census data. Journal on Chain and Network Science, 14(3): 231-245, https://doi.org/10.3920/JCNS2014.x009.

Baker W.E., Sinkula J.M., 1999. Learning orientation, market orientation, and innovation: Integrating and extending models of organizational performance. 
Journal of Market-focused Management, 4(4): 295 308, https://doi.org/10.1023/A:100983040.

Brodt S., Klonsky K., Tourte L., Duncan R., Hendricks L., Ohmart C., Verdegaal P., 2004. Influence of farm management style on adoption of biologically integrated farming practices in California. Renewable Agriculture and Food Systems, 19(4): 237-247, https://doi.org/10.1079/RAFS200488.

Buchanan H., McDermott P.A., Schaefer B.A., 1998. Agreement among classroom observers of children's stylistic learning behaviors. Psychology in the Schools, 35(4): 355-361, https://doi.org/10.1002/ (SICI) 1520-6807(199810)35:4<355::AIDPITS6>3.0.CO;2-5.

Calantone R.J., Cavusgil S.T., Zhao Y., 2002. Learning orientation, firm innovation capability, and firm performance. Industrial Marketing Management, 31(6): 515-524, https://doi.org/10.1016/S00198501(01)00203-6.

Cheng C.J., Shiu E.C., 2008. Re-innovation: The construct, measurement, and validation. Technovation, 28(10): 658-666, https://doi.org/10.1016/j.technovation.2007.08.002.

Cofré-Bravo G., Klerkx L., Englera A., 2019. Combinations of bonding, bridging, and linking social capital for farm innovation: How farmers configure different support networks. Journal of Rural Studies, 69: 53-64.

Compés López R., García Álvarez-Coque J.M., 2009. La reforma de la PAC y la agricultura española: alternativas y oportunidades para España. Madrid: Observatorio de Política Exterior Española, Fundación Alternativas, 96 pp.

Compés López R., García Álvarez-Coque J.M., Martinez Gómez V., 2019. Acuerdos comerciales, competitividad y crisis en la citricultura valenciana. Distribución y Consumo, 3: 38-46.

Connor J.M., Schiek W.A., 1997. Food processing: an industrial powerhouse in transition (2 ed.). New York: John Wiley and Sons, 666 pp.

Dedieu B., Darnhofer I., Bellon S., Greef K.D., Casabianca F., Madureira L., Milestad R., Paine M., Steyaert P., Stobbelaar D.J., Zasser-Bedoya S. (eds.), 2009. Innovations in Farming Systems Approaches. Papers presented at the European Symposium of IFSA, Clermont-Ferrand, France, 6-10 July 2008. Special issue Outlook on Agriculture, 38(2): 108-212.

Dimitratos P., Lioukas S., Carter S., 2004. The relationship between entrepreneurship and international performance: the importance of domestic environment. International Business Review, 13(1): 19-41, https://doi.org/10.1016/j.ibusrev.2003.08.001.
Dyer J.H., Gregersen H.B., Christensen C.M., 2009. The innovator's DNA. Harvard Business Review, 87(12): 61-67.

Dyer J.H., Gregersen H., Christensen C.M., 2011. The innovator's DNA: Mastering the five skills of disruptive innovators. Boston, MA: Harvard Business Press, $304 \mathrm{pp}$.

Fagerberg J., 2003. Schumpeter and the revival of evolutionary economics: an appraisal of the literature. Journal of Evolutionary Economics, 13(2): 125-159, https://doi.org/10.1007/s00191-0030144-1.

Fiss P.C., 2007. A set-theoretic approach to organizational configurations. Academy of Management Review, 32(4): 1180-1198, https://doi.org/10.5465/ amr.2007.26586092.

Fiss P.C., 2011. Building better causal theories: A fuzzy set approach to typologies in organization research. Academy of Management Journal, 54(2): 393-420, https://doi.org/10.5465/amj.2011.60263120.

Fortuin F.T., Omta S.W.F., 2009. Innovation drivers and barriers in food processing. British Food Journal, 111(8): 839-851, https://doi. org/10.1108/00070700910980955.

Furtan W.H., Sauer J., 2008. Determinants of food industry performance: survey data and regressions for Denmark. Journal of Agricultural Economics, 59(3): 555-573, https://doi.org/10.1111/j.14779552.2008.00164.x.

García Álvarez-Coque J.M., Lopez-Garcia Usach T., Sanchez Garcia M., 2012. Territory and innovation behaviour in agri-food firms: does rurality matter? Presented at $126^{\text {th }}$ EAAE Seminar, New challenges for EU agricultural sector and rural areas. Which role for public policy?, Capri, Italy, June 27-29. https://ageconsearch.umn.edu/record/126030.

García Álvarez-Coque J.M., Mas-Verdú F., Roig-Tierno N., 2017. Technological innovation versus non-technological innovation: different conditions in different regional contexts?. Quality \& Quantity, 51(5), 1955-1967, https://doi.org/10.1007/s11135016-0394-2.

García Álvarez-Coque J.M., Pérez Ledo P., Santarremigia Casañ E., 2014. Perfiles innovadores en la agricultura valenciana. Cuadernos de Estudios Agroalimentarios (CEA), 6: 153-169. http://hdl. handle.net/10251/53592.

García Álvarez-Coque J.M., Sandoval R.R., MasVerdú F., 2018. Do research and extension services improve small farmers' perceived performance? New Medit, 17(4): 8-19.

García Ferrando M., López-Aranguren E., Beltrán M., 1994. La conciencia nacional y regional en la Es- 
paña de las Autonomías. Madrid: Centro de Investigaciones Sociológicas.

Hauser M., Aigelsperger L., Owamani A., Delve R.J., 2010. Learning achievements of farmers during the transition to market-oriented organic agriculture in rural Uganda. Journal of Agriculture and Rural Development in the Tropics and Subtropics (JARTS), 111(1), 1-11.

Hollenstein H., 1996. A composite indicator of a firm's innovativeness. An empirical analysis based on survey data for Swiss manufacturing. Research Policy, 25(4): 633-645, https://doi.org/10.1016/00487333(95)00874-8.

Hsieh C.T., Miguel E., Ortega D., Rodriguez F., 2011. The price of political opposition: Evidence from Venezuela's Maisanta. American Economic Journal: Applied Economics, 3(2): 196-214, DOI: 10.1257/app.3.2.196.

Hult G.T.M., Snow C.C., Kandemir D., 2003. The role of entrepreneurship in building cultural competitiveness in different organizational types. Journal of Management, 29(3): 401-426, https://doi. org/10.1016/S0149-2063_03_00017-5.

Hurley R.F., Hult G.T.M., 1998. Innovation, market orientation, and organizational learning: an integration and empirical examination. Journal of Marketing, 62(3): 42-54, https://doi. org/10.1177/002224299806200303.

Hurt H.T., Joseph K., Cook C.D., 1977a. Scales for the measurement of innovativeness. Human Communication Research, 4(1): 58-65, https://doi. org/10.1111/j.1468-2958.1977.tb00597.x.

Hurt H.T., Teigen C.W., 1977b. The development of a measure of perceived organizational innovativeness. Annals of the International Communication Association, 1(1): 377-385, https://doi.org/10.1080 /23808985.1977.11923693.

Jaw C., Lo J.Y., Lin Y.H., 2010. The determinants of new service development: Service characteristics, market orientation, and actualizing innovation effort. Technovation, 30(4): 265-277, https://doi. org/10.1016/j.technovation.2009.11.003.

Johnson R.J., Doye D., Lalman D.L., Peel D.S., Raper K.C., Chung C., 2010. Factors affecting adoption of recommended management practices in stocker cattle production. Journal of Agricultural and Applied Economics, 42(1): 15-30, https://doi.org/10.1017/ S1074070800003266.

Keskin H., 2006. Market orientation, learning orientation, and innovation capabilities in SMEs: An extended model. European Journal of Innovation Management, 9(4): 396-417, https://doi. org/10.1108/14601060610707849.
Klerkx L., van Mierlo B., Leeuwis C., 2012. Evolution of systems approaches to agricultural innovation: concepts, analysis and interventions. In: Darnhofer I., Gibbon D., Dedieu B. (eds.), Farming Systems Research into the 21st century: The new dynamic. Dordrecht: Springer, pp. 457-483, https:// doi.org/10.1007/978-94-007-4503-2_20.

Kohli A.K., Jaworski B.J., Kumar A., 1993. MARKOR: a measure of market orientation. Journal of Marketing Research, 30(4): 467-477, https://doi. org/10.1177/002224379303000406.

Maghni B., Oukaci K., 2018. Sources of innovation in family olive farms: the case of Bejaia province in Algeria. New Medit, 17(1): 23-35.

Magne C., Gordon R.L., Midha S., 2010. Influence of metrical expectancy on reading words: An ERP study. Speech Prosody 2010-Fifth International Conference. Available at: http://citeseerx.ist.psu.edu/viewdoc/ download?doi=10.1.1.302.6043\&rep=rep1\&type $=$ pdf

McCrae R.R., Costa, P.T. Jr., 1999. A five-factor theory of personality. In: Pervin L.A., John O.P. (eds.), Handbook of Personality: Theory and Research (2 ed.). New York: Guilford, pp. 139-153.

Micheels E.T., Nolan J.F., 2016. Examining the effects of absorptive capacity and social capital on the adoption of agricultural innovations: a Canadian Prairie case study. Agriculture Systems, 145: 127-138.

Mutsvangwa-Sammie E.P., Manzungu E., Siziba S., 2017. Profiles of innovators in a semi-arid smallholder agricultural environment in south west Zimbabwe. Physics and Chemistry of the Earth, Parts $A / B / C$, 100: 325-335, https://doi.org/10.1016/j. pce.2016.09.002.

$\mathrm{Ng} \mathrm{T.,} \mathrm{Feldman} \mathrm{D.,} \mathrm{2013.} \mathrm{A} \mathrm{meta-analysis} \mathrm{of} \mathrm{the} \mathrm{rela-}$ tionships of age and tenure with innovation-related behavior. Journal of Occupational and Organizational Psychology, 86(4): 585-616.

Nieto Alemán P.A., Roig-Tierno N., Mas-Verdú F., García Álvarez-Coque J.M., 2018. Multidimensional paths to regional poverty: a Fuzzy-set qualitative comparative analysis of Colombian departments. Journal of Human Development and Capabilities, 19(4): 499-520.

Okamuro H., 2007. Determinants of successful R\&D cooperation in Japanese small businesses: The impact of organizational and contractual characteristics. Research Policy, 36(10): 1529-1544, https:// doi.org/10.1016/j.respol.2006.12.008.

Parsons R.A., 2015. The impact of age on innovation. Management Research Review, 38(4): 404-420.

Picazo Tadeo A.J., Hernández Sancho F., 1993. Tipologías agrarias valencianas. Revista de Estudios Agrosociales, 164: 75-91. 
Prokopy L.S., Floress K., Klotthor-Weinkauf D., Baumgart-Getz A., 2008. Determinants of agricultural best management practice adoption: Evidence from the literature. Journal of Soil and Water Conservation, 63(5): 300-311, doi:10.2489/jswc.63.5.300.

Ragin C.C., 2000. Fuzzy-set social science. Chicago: University of Chicago Press, 332 pp.

Ragin C.C., 2006. Set relations in social research: Evaluating their consistency and coverage. Political Analysis, 14(3): 291-310, https://doi.org/10.1093/ pan/mpj019.

Ragin C.C., 2008. Redesigning social inquiry: Fuzzy sets and beyond. Chicago: University of Chicago Press, $224 \mathrm{pp}$.

Rauch A., Wiklund J., Lumpkin G.T., Frese M., 2009. Entrepreneurial orientation and business performance: An assessment of past research and suggestions for the future. Entrepreneurship Theory and Practice, 33(3): 761-787, https://doi.org/10.1111/ j.1540-6520.2009.00308.x.

Rezai G., Mohamed Z., Shamsudin M.N., 2011. Informal education and developing entrepreneurial skills among farmers in Malaysia. World Academy of Science, Engineering and Technology, 79: 254-261.

Rogers E.M., 2003. Diffusion of innovation ( $3^{\text {rd }}$ ed.). New York: The Free Press.

Röling N., 1990. The agricultural research-technology transfer interface: a knowledge systems perspective. In: Kaimowitz D. (ed.), Making the link; agricultural research and technology transfer in developing countries. Boulder: Westview Press, with International Service for National Agricultural Research, pp. 1-42.

Rossberger R.J., 2014. National personality profiles and innovation: The role of cultural practices. Creativity and Innovation Management, 23(3): 331348, https://doi.org/10.1111/caim.12075.

Ruttan V.W., 2000. Technology, Growth and Development: An Induced Innovation Perspective. Oxford-New York: Oxford University Press.
Schneider C.Q., Wagemann C., 2010. Standards of good practice in qualitative comparative analysis (QCA) and fuzzy-sets. Comparative Sociology, 9(3): 397-418, https://doi.org/10.1163/15691321 0X12493538729793.

Segarra-Blasco A., Arauzo-Carod J.M., 2008. Sources of innovation and industry-university interaction: Evidence from Spanish firms. Research Policy, 37(8): 1283-1295, https://doi.org/10.1016/j. respol.2008.05.003.

Sidhu I, Goubet J.E., Webber H., Fredh-Ojala A., Johnsson C., Pries J.C., 2016. Berkeley Innovation Index: an approach for measuring and diagnosing individual's and organizations' innovation capabilities. Berkeley: Sutardja Center for Entrepreneurship and Technology. https://scet.berkeley. edu/wp-content/uploads/Berkeley-Innovation-Index-Concept-Paper.pdf.

Sophonthummapharn K., 2009. The adoption of techno-relationship innovations: a framework for electronic customer relationship management. Marketing Intelligence \& Planning, 27(3): 380-412, https://doi.org/10.1108/02634500910955254.

Steel Z., Momartin S., Silove D., Coello M., Aroche J., Tay K.W., 2011. Two year psychosocial and mental health outcomes for refugees subjected to restrictive or supportive immigration policies. Social Science \& Medicine, 72(7): 1149-1156, https://doi.org/10.1016/j.socscimed.2011.02.007.

Zhou K.Z., Gao G.Y., Yang Z., Zhou N., 2005a. Developing strategic orientation in China: antecedents and consequences of market and innovation orientations. Journal of Business Research, 58(8): 1049-1058, https://doi.org/10.1016/j.jbusres.2004.02.003.

Zhou K.Z., Yim C.K., Tse D.K., 2005b. The effects of strategic orientations on technology-and market-based breakthrough innovations. Journal of Marketing, 69(2): 42-60, https://doi.org/10.1509/ jmkg.69.2.42.60756. 